\title{
Phenotypic and Molecular Detection of Resistance Genes from Multi-drug Resistant Escherichia coli Isolated from Patients Attending Selected Hospitals in Damaturu, Yobe State, Nigeria
}

\author{
Sheriff Wakil ${ }^{1}$, Mustafa Alhaji Isa ${ }^{2}$, Adam Mustapa ${ }^{2}$ \\ ${ }^{1}$ Department of Microbiology, Yobe State University, Damaturu- Nigeria \\ ${ }^{2}$ Department of Microbiology, University of Maiduguri, Borno State, Nigeria \\ Corresponding Author: Sheriff Wakil
}

\begin{abstract}
Multidrug resistance among Escherichia coli causing urinary tract infections (UTIs) and diarrhea are major public health problem worldwide which cause difficulty in treating the infections caused by Escherichia coli due to the high resistances. The study is aimed to determine the phenotypic and molecular detection of multidrug resistant $E$. coli isolated from clinical samples of patients attending selected Hospitals in Damaturu, Yobe StateNigeria.

Methods: Two hundred (200) clinical samples were collected aseptically from patient diagnosed with diarrheic (100 stool samples) and UTI's (100 urine samples) using sterile universal container. The samples were processed using standard microbiological methods for identification of E. coli. Samples were cultured on MacConkey agar (stool) and Cystine lactose electrolyte deficient agar (urine). The resulting colonies of isolates were further subculture on Eosin methylene blue agar for confirmatory and followed by gram stain, biochemical identification at Microbiology laboratory unit of Yobe State Specialist and Yobe State Teaching Hospital respectively. The antimicrobial susceptibility patterns were determined using Kirby-Bauer disc diffusion techniques and the phenotypic expression of extended spectrum beta-lactamases (ESBLs) were determined using modified double disc synergy test (MDDST) and also the three (3) resistance genes (blaTEM, accCl and qnrA) were detected using polymerase chain reaction.
\end{abstract}

Results: One hundred and twenty-two (122) isolates were resistant to antibiotics. The highest level of resistance was against amoxicillin $(90.2 \%)$ while the least resistance was against sparfloxacin (24.3\%). Thirty-seven (37) E. coli isolates shows MDR; the highest MDR was (24.3\%) while least MDR was (5.4\%). The PCR amplification of resistant genes (blaTEM, accC1 and $q n r A$ ) were detected on E. coli that shows positive ESBL and the bands were separated using agarose gel electrophoresis.

Conclusion: The findings of this study show augmentin, ciprofloxacin and sparfloxacin are the most effective antibiotics against $E$. coli isolated from patients attending the two hospitals in Damaturu; who are diagnose with UTI and diarrheic infection. The resistant genes include; blaTEM, accCl and qnrA coding for beta-lactam, aminoglycoside and quinolones were present in E. coli isolated from patients attending selected Hospitals in Yobe State, Nigeria.

Keywords: Multidrug resistant, Escherichia coli, extended spectrum beta lactamase, resistanceassociated genes, urinary tract infections, diarrheic.

\section{INTRODUCTION}

During the last few decades, the incidence of microbial infections has increased dramatically. Continuous deployment of antimicrobial drugs in treating infections has led to the emergence of resistance among the various strains of 
microorganisms (Lee et al., 2013). Multidrug resistance (MDR) is insensitivity or resistance of a microorganism to the administered antimicrobial medicines (which are structurally unrelated and have different molecular targets) despite earlier sensitivity to it or process by which microorganism's resist to three or more antimicrobial classes (Singh, 2013; Popęda, 2014). According to WHO, these resistant microorganisms (like bacteria, fungi, viruses, and parasites) are able to combat attack by antimicrobial drugs, which leads to ineffective treatment resulting in persistence and spreading of infections. Although the development of MDR is a natural phenomenon, extensive rise in the number of immunocompromised conditions, like HIV-infection, diabetic patients, individuals who have undergone organ transplantation, and severe burn patients, makes the body an easy target for hospital acquired infectious diseases, thereby contributing to further spread of MDR (Nikaido, 2009; WHO,2014). Antimicrobial resistance infection is associated with high mortality rates and high medical costs and has a significant impact on the effectiveness of antimicrobial agents. MDR provokes obstruction in disease control by intensifying the possibility of spreading of resistant pathogens, thus, declining efficacy of treatment and, hence, resulting in prolonged time of infection in-patient. The cost of treatment is increase due to multiple classes of antibiotics, and some turn out to be extensively drug resistance (WHO, 2014).

Escherichia coli is the first microorganism which was described by Theodor Escherich in 1885, which is a member of the bacterial family of Enterobacteriaceae, is the most prevalent commensal inhabitant of the gastrointestinal tracts of humans and warm-blooded animals, as well as one of the most important pathogens (Kaper and Nataro, 2004). As a commensal, it lives in a mutually beneficial association with hosts, and rarely causes disease. It is, however, also one of the most common human and animal pathogens, as it is responsible for a broad spectrum of diseases. The peculiar characteristics of the E. coli, such as ease of handling, availability of the complete genome sequence, and its ability to grow under both aerobic and anaerobic condition, makes it an important host organism in biotechnology. E. coli is used in a wide variety of applications both in the industrial and medical area and it is the most used microorganism in the field of recombinant DNA technology (Yoo et al., 2009).

Transmission of Escherichia coli occurs via the fecal-oral route after consumption of contaminated, undercooked liquids and foods. Recently E. coli becomes more resistant to antimicrobials especially to cephalosporin, aminoglycoside, betalactam, quinolones and others (Chill et al., 2016; Karlawsky et al., 2017). E. coli is one of the Enterobacteriaceae strains that produce extended-spectrum beta-lactamases enzymes (ESBLs) producing bacteria and becomes highly resistant against different beta-lactam antimicrobials lead to difficult to treat diseases and as well as other class of antibiotics, hence they are called multi-drug resistant (MDR) bacteria (Nathesiwan et al., 2001). The emergence of Escherichia coli isolates with multiple antibiotic-resistant phenotypes, involving co-resistance to three or more unrelated families of antibiotics, has been previously reported and is considered a serious health concern (Pitout, 2012).

The extended spectrum $\beta$ lactamases TEM, SHV, and CTX-M are the three main types of ESBLs. CTX-M, which has become more prevalent than SHV and TEM, includes a rapidly expanding family, which has spread among a wide range of clinically important bacteria and over wide geographic areas (Yusuf and Yahaya, 2013). Furthermore, strains that produce ESBL often demonstrate resistance to antibiotics belonging to other classes (i.e. aminoglycosides, quinolones, and sulfonamides), which makes strategies of treatment more complex (Liao et al, 2017). 
The mechanism of resistance to $\beta$-lactam antimicrobial agents in E. coli is production of $\beta$-lactamase hydrolytic enzymes that disrupt the amide bond of the characteristic four-membered $\beta$-lactam ring, rendering the antimicrobial ineffective (Blair, 2015). Interestingly the $\beta$-lactamases are structurally relate to PBP's and they may have evolved from these $\beta$-lactam-binding enzymes of cell wall biosynthesis. These enzymes have been describe numerous times in both Gram-negative and Grampositive organisms and in the Mycobacteria (Yusuf and Yahaya, 2013).

Aminoglycosides are important treatments against Gram-negative infections. They are particularly active against aerobic, Gram-negative bacteria and act synergistically against certain Grampositive organisms (Jena and Deb, 2006). Aminoglycosides are a therapeutically essential class of antibiotics whose usefulness their toxic potential and residues in food animals often restrict. The aminoglycoside antimicrobial compounds are produce from strains of Streptomyces spp., Micromonospora spp., and Bacillus spp. Neomycin, streptomycin and kanamycin are examples of aminoglycosides (Shakil et al, 2008).

The primary mechanism for resistance to aminoglycosides of $E$. coli is enzymatic modification involving three families of enzymes: acetyltransferases (AAC), nucleotidyl (adenyl) transferase (ANT) and phosphotransferases (APH) (vaculenko, 2003; EFSA, 2008). Crossresistance between aminoglycosides is complex and depends on the gene(s) present (EFSA, 2008).

Quinolones are one of the most commonly prescribed classes of antibacterial in the world and they are use in treating a variety of bacterial infections in humans. Because of the wide use (and overuse) of these drugs, the number of quinolone-resistant bacterial strains has been growing steadily since the 1990s. As is the case with other antibacterial agents, the rise in quinolone resistance threatens the clinical utility of this important drug class. Quinolones act by converting their targets, gyrase and topoisomerase IV into toxic enzymes that fragment the bacterial chromosome (Drlica et al., 2009). Various community and hospital-based studies from Nigeria and other African countries have reported a varying prevalence of antimicrobial resistant and phenotypic ESBL producing Enterobacteriaceae (Ugbo et al., 2016). However, there is no information on molecular detection of $E$. coli isolates causing UTIs and diarrheic in Yobe State, Nigeria. Therefore, this study was carry out to investigate the molecular detection of resistance genes in E. coli isolated from patients diagnosed with UTIs and diarrheic in Yobe State, Nigeria.

\section{MATERIAL AND METHOD}

\subsection{Sampling site and sample collection}

The research design were carried out in two (2) hospitals in Damaturu metropolis with geographical coordinate's $12^{\circ} 00^{\prime} \mathrm{N}$ $11^{\circ} 30^{\prime} \mathrm{E} / 12.000^{\circ} \mathrm{N} 11.500^{\circ} \mathrm{E}$. The samplings were performed between the months of March 2020 to January 2021. Two hundred clinical samples were collected aseptically using a sterile universal container, 100 urine samples were collected from patients diagnose with urinary tract infections from the two hospitals and 100 stool samples were collected from patients diagnose with diarrheic from the two hospitals respectively. This study was approved by the Research Ethics Committee of the Yobe State Specialist Hospital (YSSH) and Yobe State Teaching Hospital (YSTH), Damaturu before the commencement of the study.

\subsection{Culture/Microbiological analysis}

The clinical samples collected were streak separately onto cysteine lactose and electrolyte deficient (CLED) Agar for (urine) and MacConkey agar for (stool) plates under aseptic techniques and incubated at $37^{\circ} \mathrm{C}$ for 24 hours. The resulting colonies were further sub-culture for confirmatory onto Eosin Methylene Blue 
agar and incubated at $37^{\circ} \mathrm{C}$ for 24 hours. The colonies were further identified using gram staining and biochemical techniques (citrate test, methyl red test, triple sugar iron test and indole test) (CLSI, 2016).

\subsection{Antimicrobial susceptibility testing}

The antimicrobial susceptibility testing of confirmed Escherichia coli isolates were performed on Mueller Hinton agar plates using a modified Kirby-Bauer disc diffusion technique. Ten antibiotics were used include; septrin $(30 \mu \mathrm{g})$, chloramphenicol $(30 \mu \mathrm{g}), \quad$ sparfloxacin $(10 \mu \mathrm{g})$, ciprofloxacin $(30 \mu \mathrm{g})$, amoxicillin $(30 \mu \mathrm{g})$, augmentin $(10 \mu \mathrm{g})$, gentamicin $(30 \mu \mathrm{g})$, pefloxacin $(30 \mu \mathrm{g})$, tarivid $(10 \mu \mathrm{g})$, streptomycin $(30 \mu \mathrm{g})$. The antibiotic disk was place on the surface of Mueller Hinton agar being streak with the confirmed colony of Escherichia coli, sufficiently separated from each other to avoid overlapping of inhibition zones. After 30 seconds of prediffusion, the plates were incubated at $37^{\circ} \mathrm{C}$ for 24 hours after which the diameter of inhibition zones was measure with a meter rule (CLSI, 2016).

\subsection{Phenotypic detection of extended spectrum $\beta$-lactamase (ESBLs)}

The screening for ESBLs production in all positive Escherichia coli isolates were perform using combination of modified double disc synergy test (MDDST) method. The phenotypic detection was carried out using three types of antimicrobial agents (3rd generation cephalosporin's);

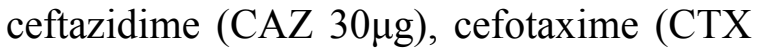

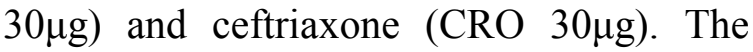
single discs of ceftazidime, cefotaxime and ceftriaxone were place on each of the isolate inoculated on Mueller Hinton agar plates and incubated at $37^{\circ} \mathrm{C}$ for 24 hours for the detection of ESBL enzymes. The zone diameter around each of the discs was measure and the diameter around ceftazidime, cefotaxime and ceftriaxone were $5 \mathrm{~mm}$ and more, the bacterial isolates produced ESBL enzymes (CLSI, 2016).

\subsection{Confirmatory test for detection of extended spectrum $\beta$-lactamase}

The confirmatory test was performed

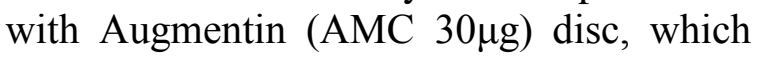
was place at the center of Mueller Hinton agar plate containing the streaked colonies of the positive isolate. Three discs

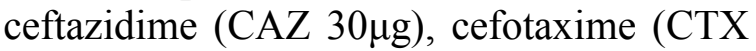

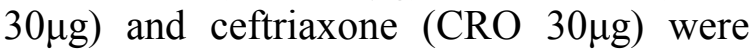
place at side of Augmentin (AMC 30 $\mu \mathrm{g}$ ) disc with distance of $15 \mathrm{~mm}$ from center; the plates were incubated overnight at $37^{\circ} \mathrm{C}$ for 24 hours. The zone of inhibitions towards

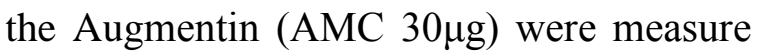
for positive production of ESBL (CLSI, 2016).

\subsection{DNA extraction for PCR amplification}

The DNA templates of each of the confirmed pure Escherichia coli isolates were generate by dispensing most of the pure colonies of overnight growth of the isolates onto 100- $\mu \mathrm{L} 1 \mathrm{X}$ Tris- EDTA buffer, vortex mixed and boiled at $100^{\circ} \mathrm{C}$ for 10 minutes. Then it was transferred immediately to the freezer $\left(-20^{\circ} \mathrm{C}\right)$ for 10 minutes, maintained at room temperature, vortex mixed again and centrifuged at $10,000 \mathrm{rpm}$ for 10 minutes. The resulting supernatant containing DNA templates of the isolates were separate, stored at $4{ }^{\circ} \mathrm{C}$, and used as DNA template for PCR amplification (Yang et al., 2008).

\subsubsection{Molecular detection of ESBLs associated resistance genes}

The polymerase chain reaction (PCR) was perform for beta-lactamase (blaTEM), aminoglycoside (accCl) and quinolones (qnrA) to detect the presence of extended spectrum beta-lactamase encoding genes and PCR analysis was carried out at Nigerian Institute for Trypanosomiasis Research Kaduna State, Nigeria. The PCR was carried out for eight (8) randomly selected ESBLs positives using a primer in (Table 1) and the PCR amplification was carried in a MyGene $^{\mathrm{TM}}$ Series Peltier Thermal Cycler MG96 (LongGene 
Scientific Instruments Co. Ltd. China). The amplification mixture was all the same for three resistant genes (blaTEM, accCl and $q n r A)$ respectively. The amplification reaction was carried out using $(1 \mu \mathrm{l})$ DNA templet, $(1 \mu \mathrm{l})$ each forward and reverse primers (from Inqaba Biotec, West Africa Ltd.) and $(17 \mu l)$ of PCR premix contain all PCR products (HotStart from Bioneer Company, South Korea) which make complete $(20 \mu \mathrm{l})$ reaction mixture (Zhang et al., 2019). The amplification conditions used for each gene were as follows:

\subsubsection{Amplification of the blaTEM resistance genes}

The blaTEM resistant gene was amplified using initial denaturation at $95^{\circ} \mathrm{C}$ for $5 \mathrm{~min} ; 35$ cycles of $94^{\circ} \mathrm{C}$ for $30 \mathrm{sec}, 52^{\circ} \mathrm{C}$ for $30 \mathrm{sec}$ and $72^{\circ} \mathrm{C}$ for $45 \mathrm{sec}$; and final elongation step at $72^{\circ} \mathrm{C}$ for $7 \mathrm{~min}$. The annealing temperature was $52^{\circ} \mathrm{C}$ for blaTEM gene (Ensor et al., 2009).

\subsubsection{Amplification of the accC1 resistance genes}

The accCl resistant gene was amplified using initial denaturation at $95^{\circ} \mathrm{C}$ for $5 \mathrm{~min}$; 35 cycles of $94^{\circ} \mathrm{C}$ for $1 \mathrm{~min}, 55^{\circ} \mathrm{C}$ for $1 \mathrm{~min}$ and $72^{\circ} \mathrm{C}$ for $2 \mathrm{~min}$; and final elongation step at $72^{\circ} \mathrm{C}$ for $5 \mathrm{~min}$. The annealing temperature was $55^{\circ} \mathrm{C}$ for $a c c C 1$ gene (Hujer et al., 2006).

\subsubsection{Amplification of the $q n r A$ resistance genes}

The qnrA resistant gene was amplified using initial denaturation at $95^{\circ} \mathrm{C}$ for $5 \mathrm{~min}$; 35 cycles of $94^{\circ} \mathrm{C}$ for $1 \mathrm{~min}, 55^{\circ} \mathrm{C}$ for $1 \mathrm{~min}$ and $72^{\circ} \mathrm{C}$ for $2 \mathrm{~min}$; and final elongation step at $72^{\circ} \mathrm{C}$ for $5 \mathrm{~min}$. The annealing temperature was $55^{\circ} \mathrm{C}$ for accC1 gene (Robicsek et al., 2006).

\section{RESULTS}

Table 1: The three (3) resistance genes used in this study are (blaTEM, accCl and $q n r A)$ and the detection of the genes were perform using a primer by previous studies.

Table 2: One hundred and twenty two (122) Escherichia coli positive isolates were obtain from two hundred (200) samples; one hundred (100) samples from each hospital. The table shows the prevalence of Escherichia coli in stool and urine samples. Only 23 of the 61 stools were positive for Escherichia coli, which corresponded to an isolation rate of $37.7 \%$. Only 99 of the 139 urine samples gave positive Escherichia coli and hence prevalence rate of $71.2 \%$.

Table 3: Reveals the multi-drug resistance (MDR) pattern of 37 Escherichia coli isolates. The MDR patterns in the table were comprised of Yobe State Specialist and Yobe State Teaching Hospitals in Damaturu respectively. Under the Y.S.S.H (21) isolates were found to be resistance to three and above antibiotics; the highest level of MDR is $5(23.8 \%)$ and the least is 1 (4.8 $\%)$. While (16) isolates were found to have three and above antibiotics at Y.S.T.H; the highest level MDR is $5(31.3 \%)$ and the least is $1(6.3 \%)$. Then, the combined MDR of the both hospitals were found to be 37 isolates and the highest level of MDR was found to be $9(5.4 \%)$ while the least is 2 $(5.3 \%)$ respectively.

Table 4: Shows the total number of positive samples for extended betalactamase and non- extended beta lactamase producing Escherichia coli among the MDR isolates. Among the (122) positive isolates were obtained in stool and urine from clinical samples of patients in the Y.S.S.H and Y.S.T.H Damaturu. Only (34) isolates were producing extended spectrum beta lactamase: $12(32.3 \%)$ stool and 22 (64.7 $\%$ ) urine from the clinical samples of the both hospitals. Meanwhile, the remaining (88) isolates were found non-extended spectrum beta lactamase producing organisms; $11(12.5 \%)$ stool and 77 (87.5 $\%)$ respectively. 
Sheriff Wakil et.al. Phenotypic and molecular detection of resistance genes from multi-drug resistant Escherichia coli isolated from patients attending selected hospitals in Damaturu, Yobe State, Nigeria.

Table 1: Primers used in PCR for (3) antimicrobial resistance genes of Escherichia coli

\begin{tabular}{|c|c|c|c|c|}
\hline Groups of antibiotics & Resistance genes & $\begin{array}{l}\text { Product size } \\
\text { (bp) }\end{array}$ & Primers & References \\
\hline Beta-lactam & blaTEM & 680 & $\begin{array}{l}\text { F:5'-CAGCGGTAAGATCCTTGAGA-3' } \\
\text { R:5'-ACTCCCCGTCGTGTAGATAA-3' }\end{array}$ & Ensor et al., 2009 \\
\hline Aminoglycoside & accC1 & 890 & $\begin{array}{l}\text { F:5'-ATGGGCATCATTCGCACATGTAGG-3' } \\
\text { R: 5'-TTAGGTGGCGGTACTTGGGTC-3' }\end{array}$ & Hujer et al., 2009 \\
\hline Quinolones & $q n r A$ & 810 & $\begin{array}{l}\text { F: 5'-ATTTCTCACGCCAGGATTTG-3' } \\
\text { R: 5'-GATCGGCAAAGGTTAGGTCA-3' }\end{array}$ & Robicsek et al.,2009 \\
\hline
\end{tabular}

Table 2: Prevalence of Escherichia coli isolated from clinical samples of patients attending Y.S.S.H and Y.S.T.H Damaturu.

\begin{tabular}{|l|l|c|c|}
\hline Sample & Source & Number (\%) of collected samples & Number (\%) positive for $\boldsymbol{E}$. coli \\
\hline Stool & Y.S.S.H & $31(50.8)$ & $15(48.4)$ \\
& Y.S.T.H & $30(4.2)$ & $8(26.7)$ \\
& Total & $\mathbf{6 1}(\mathbf{1 0 0})$ & $\mathbf{2 3 ( 3 7 . 7 )}$ \\
\hline Urine & Y.S.S.H & $69(49.6)$ & $45(65.2)$ \\
& Y.S.T.H & $70(50.4)$ & $54(77.1)$ \\
& Total & $\mathbf{1 3 9}(\mathbf{1 0 0})$ & $\mathbf{9 9}(\mathbf{7 1 . 2})$ \\
\hline
\end{tabular}

KEY: Y.S.S.H = Yobe State Specialist Hospital, Damaturu.

Y.S.T.H = Yobe State Teaching Hospital, Damaturu.

Table 3: Multi-drug resistant pattern of Escherichia coli isolated from clinical samples of patient attending Y.S.S.H and Y.S.T.H Damaturu.

\begin{tabular}{|c|c|c|c|c|c|}
\hline $\begin{array}{l}\mathbf{S} / \\
\mathbf{N}\end{array}$ & $\begin{array}{l}\text { Number of Combination of Antibiotics } \\
\text { Antibiotics }\end{array}$ & $\begin{array}{c}\text { Y.S.S.H } \\
\text { Isolates } \\
(\%) \\
(\mathbf{n}=\mathbf{2 1})\end{array}$ & Number of Combination of Antibiotics & $\begin{array}{c}\text { Y.S.T.H } \\
\text { Isolates } \\
(\%) \\
(\mathbf{n}=16)\end{array}$ & $\begin{array}{c}\text { Multi Drug } \\
\text { Resistant Isolates } \\
\text { Combined }(\%) \\
(\mathbf{n}=\mathbf{3 7})\end{array}$ \\
\hline 1 & $3 \mathrm{AM}, \mathrm{CPX}, \mathrm{AU}$ & $3(14.3)$ & $3 \mathrm{CPX}, \mathrm{AU}, \mathrm{SP}$ & $2(12.5)$ & $5(13.5)$ \\
\hline 2 & 3 AM, SXT, CPX & $5(23.8)$ & $3 \mathrm{AM}, \mathrm{CPX}, \mathrm{AU}$ & $1(6.3)$ & $6(16.2)$ \\
\hline 3 & 4 AM, SXT, SP, CPX & $1(4.8)$ & $4 \mathrm{AM}, \mathrm{CPX}, \mathrm{AU}, \mathrm{OFX}$ & $2(12.5)$ & $3(8.1)$ \\
\hline 4 & $5 \mathrm{AM}, \mathrm{SXT}, \mathrm{CH}, \mathrm{SP}, \mathrm{CPX}$ & $3(14.3)$ & $5 \mathrm{AM}, \mathrm{CPX}, \mathrm{AU}, \mathrm{OFX}, \mathrm{S}$ & $3(18.8)$ & $6(16.2)$ \\
\hline 5 & 6 AM, SXT, CH, SP, CPX, OFX & $4(19.0)$ & 6 AM, CPX, AU, CN, OFX, S & $5(31.3)$ & $9(24.3)$ \\
\hline 6 & 7 AM, SXT, CH, SP, CPX, CN, OFX & $2(9.5)$ & 7 AM, SXT, CPX, AU, CN, OFX, S & $0(0.0)$ & $2(5.4)$ \\
\hline 7 & $8 \mathrm{AM}, \mathrm{SXT}, \mathrm{CH}, \mathrm{SP}, \mathrm{CPX}, \mathrm{CN}, \mathrm{OFX}, \mathrm{S}$ & $0(0.0)$ & 8 AM, SXT, CPX, AU, CN, PEF, OFX, S & $3(18.8)$ & $3(8.1)$ \\
\hline 8 & 9 AM, SXT, CH, SP, CPX, CN, PEF, OFX, S & $3(14.3)$ & 9 AM, SXT, CH, CPX, AU, CN, PEF, OFX, S & $0(0.0)$ & $3(8.1)$ \\
\hline
\end{tabular}

KEY: $\mathrm{AM}=$ Amoxicillin, $\mathrm{SXT}=$ Septrin, $\mathrm{CH}=$ Chloramphenicol, $\mathrm{SP}=$ Sparfloxacin, $\mathrm{CPX}=\mathrm{Ciprofloxacin}, \mathrm{AU}=\mathrm{Augmentin}, \mathrm{CN}=$ Gentamycin, $\mathrm{PEF}=$ Pefloxacin, $\mathrm{OFX}=$ Nalidic Acid, $\mathrm{S}=$ Streptomycin

Y.S.S.H = Yobe State Specialist Hospital, Damaturu, Y.S.T.H = Yobe State Teaching Hospital, Damaturu.

Table 4: Total numbers and percentage of ESBL - producing and non- ESBL Escherichia coli isolated from clinical samples of patients attending Y.S.S.H and Y.S.T.H Hospital Damaturu.

\begin{tabular}{|c|c|c|c|c|}
\hline Sources of Isolates & $\begin{array}{c}\text { Y.S.S.H } \\
\mathbf{n = 6 0}\end{array}$ & $\begin{array}{c}\text { Y.S.T.H } \\
\mathbf{n = 6 2}\end{array}$ & $\begin{array}{c}\text { ESBL producing } \text { E. coli }(\boldsymbol{\%}) \\
\mathbf{n = 3 4}\end{array}$ & $\begin{array}{c}\text { Non-ESBL producing } \boldsymbol{E} \text {. coli }(\boldsymbol{\%}) \\
\mathbf{n}=\mathbf{8 8}\end{array}$ \\
\hline Stool & 15 & 8 & $12(35.3)$ & $11(12.5)$ \\
\hline Urine & 45 & 54 & $22(64.7)$ & $77(87.5)$ \\
\hline Total & $\mathbf{6 0}$ & $\mathbf{6 2}$ & $\mathbf{3 4}(\mathbf{1 0 0})$ & $\mathbf{8 8}(\mathbf{1 0 0})$ \\
\hline
\end{tabular}

KEY: ESBL $=$ Extended spectrum beta lactamase,

Y.S.S.H = Yobe State Specialist Hospital, Damaturu, Y.S.T.H = Yobe State Teaching Hospital Damaturu.
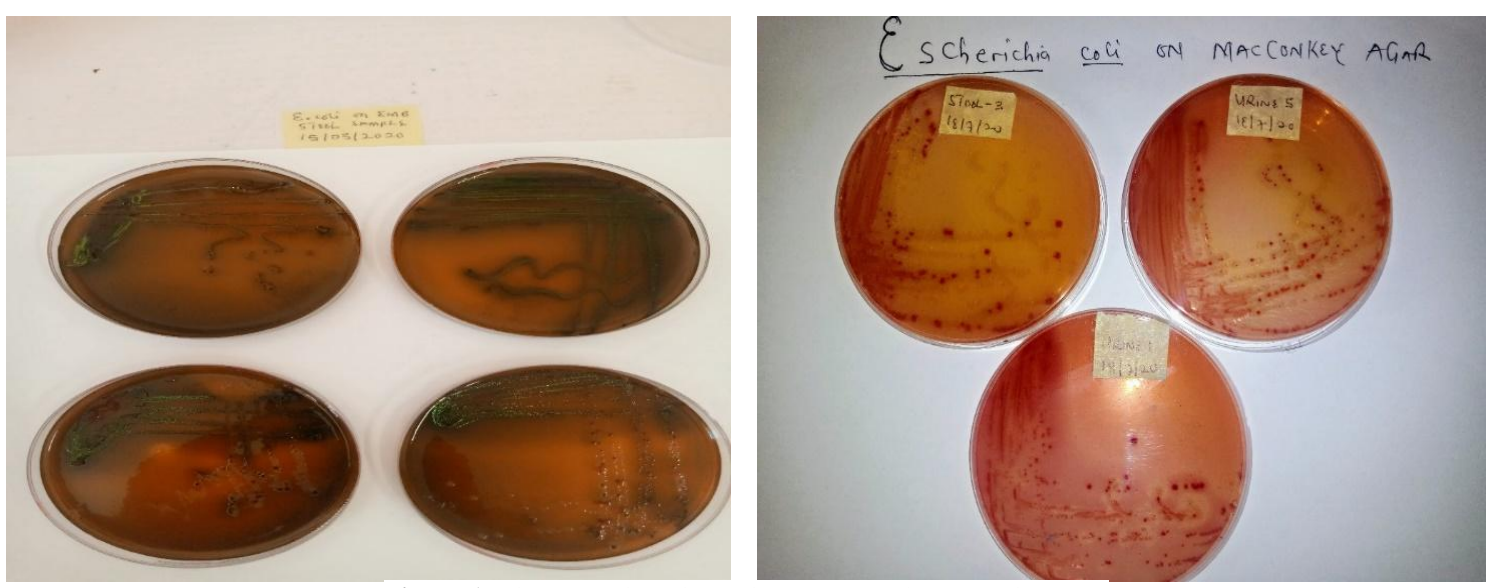

Figure 1: Shows Escherichia coli on EMB and MacConkey agar 
Sheriff Wakil et.al. Phenotypic and molecular detection of resistance genes from multi-drug resistant Escherichia coli isolated from patients attending selected hospitals in Damaturu, Yobe State, Nigeria.

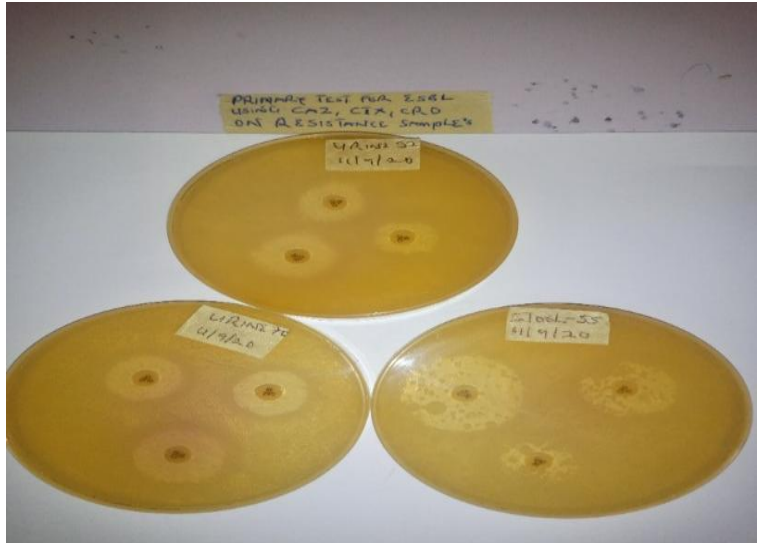

Figure 2: Shows primary test for extended spectrum betalactamase (ESBLs)

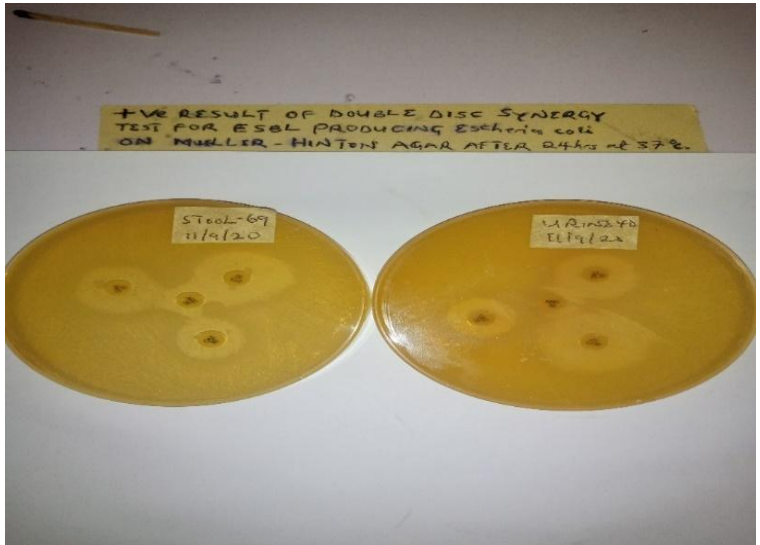

Figure 3: Shows confirmatory test for extended spectrum betalactamase (ESBLs)

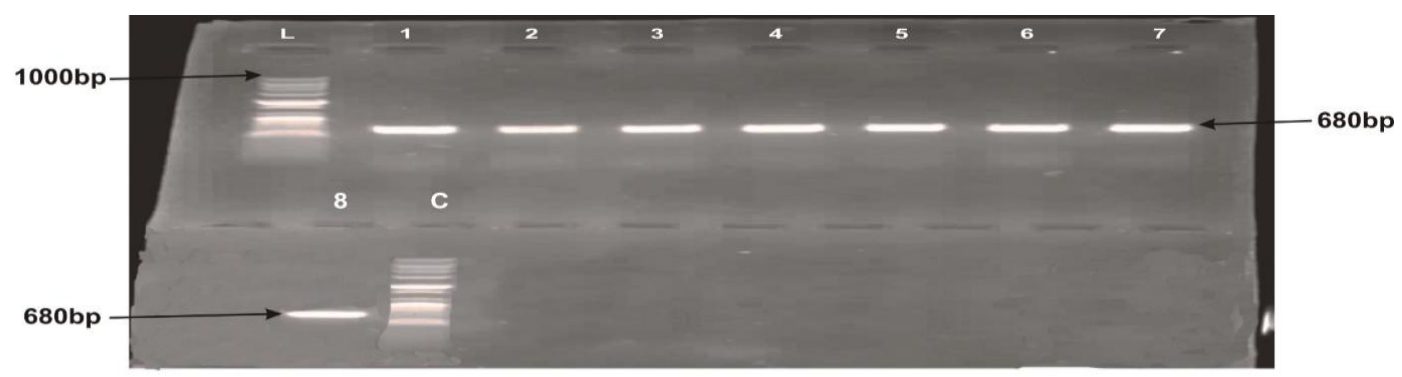

Fig 4: PCR amplified products from extracted DNA of 8 positive ESBL producing Escherichia coli, amplified with blaTEM gene shows positive results at $680 \mathrm{bp}$.

L: DNA Molecular Ladder

C: Positive Control Sample

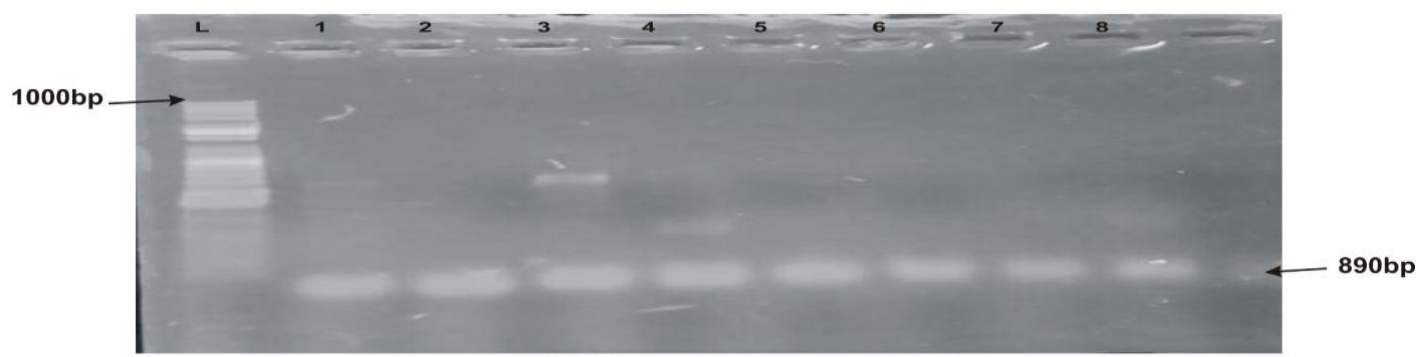

Fig 5: PCR amplified products from extracted DNA of 8 positive ESBL producing Escherichia coli, amplified with accC1 gene shows positive results at $890 \mathrm{bp}$.

L: DNA Molecular Ladder

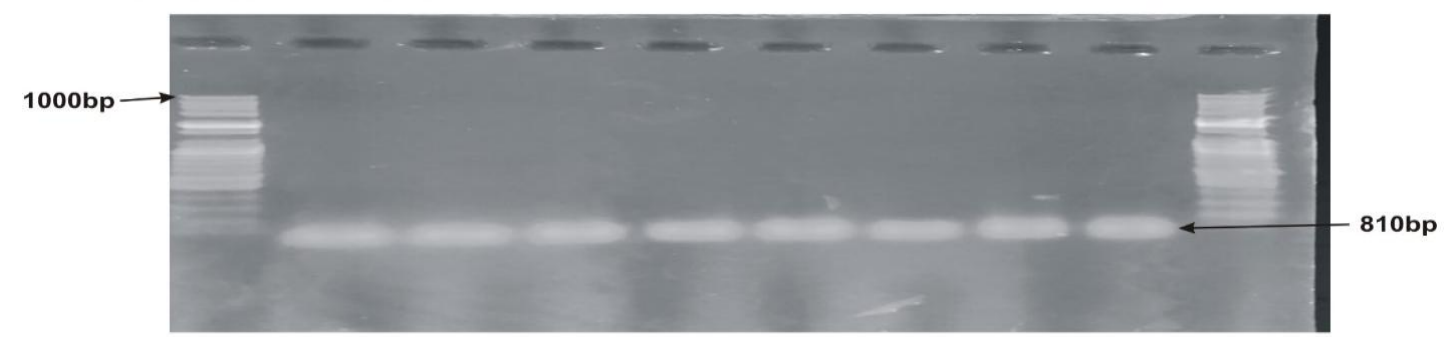

Fig 6: PCR amplified products from extracted DNA of 8 positive ESBL producing Escherichia coli, amplified with qnrA gene shows positive results at $810 \mathrm{bp}$.

L: DNA Molecular Ladder

C: Positive Control Sample

Figure 4, 5 and 6: Shows PCR representative gel for the detection of resistance genes of blaTEM, accC1 and $q n r A$ respectively.

\section{DISCUSSION}

The main goal/aims of this study was to investigate the prevalence of multidrug resistance in Escherichia coli, ESBLs producing and molecular detection of antimicrobial resistance-associated genes (blaTEM, accCl and qnrA) in Escherichia coli isolated from patients diagnosed with urinary tract and diarrheic infections in Yobe State Specialist and Yobe State 
teaching hospitals Damaturu, Nigeria. E. coli is one of the major causes of UTIs and diarrheic infection affecting humans of all ages. The emergence of multidrug resistance (MDR) Escherichia coli strains and the progressive rise in antimicrobial resistance threatens the effective treatment of UTIs and diarrheic infection leading to increased morbidity, prolonged hospital stays, increase in the cost of treatment and disease related mortality (Stefano et al., 2013). This early detection of antimicrobial resistance of the $E$. coli in a particular region will help to quick adapting strategies that can reduce the potential misuse of antimicrobial agents and prevent the emergence and subsequent spread of such multidrug resistance isolates (Salah et al., 2016).

The antimicrobial susceptibility pattern of one hundred and twenty two (122) Escherichia coli in this study shows that most isolates of $E$. coli were resistant to antimicrobial especially third generation cephalosporin's, but $37 \%$ isolates of $E$. coli were found to be resistance to three and above class of antibiotics and hence called multidrug resistant (MDR). The MDR rate in this study range from $24.3 \%$ while $5.4 \%$ lower MDR among (Table 3). In addition, in this study, UTIs isolates were the most common ESBLs producing strains with $64.7 \%$ followed by diarrheic isolates with $35.3 \%$ (Table 4).

In this study, the MDR and ESBL producing $E$. coli was significantly observe in isolate obtain in urine and this was similar to previous findings, which were significantly associated with the increased resistance of $E$. coli to beta-lactam, aminoglycoside and quinolones (Roshan et al., 2011). Most E. coli strains may be having natural resistance to beta-lactam antibiotics mostly ampicillin, amoxicillin and clavulanic acid and the resistance to ESBLs could happen in class A chromosome beta-lactamase TEM and SHV genes are expressed (Salah et al., 2016). These genes are capable of enabling bacteria to resist to different antimicrobial agents including third generation cephalosporin, aminoglycosides and others (Essack et al., 2004). In Iraq, the prevalence of MDR Enterobacteriaceae and ESBLs producing gram negative bacteria has been reported by some researcher (Al-mayahie, 2013). In addition, it was reported at previous findings that $E$. coli had the highest resistance to the all drugs tested (Adam and Turgut, 2019). Quinolone and gentamicin which were among effective agents of choice relies for treatment of most bacterial infections in the last one decade were now observed in this study to be largely ineffective on these $E$. coli isolates. The increasing level of resistance has reported in recent studies from other developing countries where there is no strict policy on the use of antibiotics in their communities (Muhammad and Swedan, 2015). The high effectiveness of sparfloxacin, augmentin and ciprofloxacin against the $E$. coli in this study on the treatment of UTI and diarrheic infection caused by $E$. coli support the previous findings (Muhammad et al., 2015, Abujnah et al., 2015 and Salah et al., 2016). Hence, the known effectiveness of colistin, nitrofurantoin and cefoperazone on UTI and diarrheic infection that caused by $E$. coli in combination with augmentin, ciprofloxacin and sparfloxacin can be used in treatment of such infections. Although, nitrofurantoin is an oldest UTI drug, which is not un-like to be attributed to, its unpleasant side effects that has largely discourage its frequent misuse and this support previous findings (Muhammad et al., 2015 and Abujnah et al., 2015). The combined multidrug resistance in this study was $37 \%$ (Table 3) which is around the previously reported findings of $39-85 \%$ in various parts of Nigeria and other African countries (Aboderin et al., 2009, Anago et al.,2015 Ugbo et al., 2016, Salah et al.,2016, Adebola et al., 2019 and Olaruntoba et al., 2020). The observed differences might be due to differences in the screening methods used in the selected hospitals in Yobe State during this study. However, the observed prevalence rate of MDR in this study indicates that the isolates obtained might have been expose to these 
antimicrobial agents from either clinics or agricultural products since $E$. coli can easily be expose to the drugs used in animal husbandry and food industry during the processing to ingestion. These necessitate the controlling of using drugs in both clinical and agricultural usage to avoid or reduce the prevalence of MDR in patients.

The phenotypic detection of ESBLs in this study were identified with 34\% (Table 4) of the E. coli isolates using modified double disc synergy test (MDDST) that is ceftazidime, cefotaxime and ceftriaxone combination discs which has higher percentage with previous finding 24\% (Adebola et al., 2019). However, the percentage in this study was high because the use of the multiple discs including augmentin, ceftazidime, cefotaxime and ceftriaxone during the screening of ESBLs enhanced the highest rates of detection among the positive isolates obtained from the selected hospitals in Yobe State, Nigeria. Also, the finding in this study shows high percentage with previous studies in Amassoma, South-Southern with 9.6\%, Oshogbo, South-Southern Nigeria with $26 \%, 6.7 \%$ in Libya, 25\% in Cotonou, Benin Republic and $22.3 \%$ in Iran respectively (Onanuga and Selekere, 2016, Ogbolu et al., 2011, Abujnah et al., 2015, Anago et al., 2015 and Ahadiri et al., 2014). The higher prevalence of ESBLs in this study were almost the same with previous studies reported at Benin South-Southern Nigeria with $44.4 \%$, Jordan with $54 \%$ and Togo with $93.4 \%$ respectively (Ogefere $e t$ al., 2015, Muhammad and Swedan, 2015 and Salah et al., 2016). The prevalence of ESBLs producing UTI and diarrheic infection caused by $E$. coli is a worldwide problems which has different degree of raised according to each counties from region to regions and its significantly associated with the extensive use of broad spectrum antibiotics especially third generation cephalosporins which has been progressively increasing in many countries (Bora et al., 2014). There are differences in the screening procedure of ESBLs producing E. coli across the various study centers, which might contribute to the observed different varying values above.

The molecular detection of ESBLs resistance genes in this study carried out with eight (8) positive isolates randomly selected from clinical samples of the both hospitals in Yobe State, Nigeria. The PCR amplification of resistance genes (blaTEM, accCl and qnrA) from this study reveals that all eight (8) positive isolates shows the resistant genes (Fig 4, 5 and 6). The resistant genes obtained from this study were similar to various previous studies (Oloruntoba et al., 2020, Muhammad and Swedan, 2015, Anago et al., 2015 and Machado et al., 2007). Likewise, the findings on resistant genes in this study correspond with many previous studies (Momtaz et al., 2012, Ensor et al., 2009, Robicsek et al., 2006, Hujer et al., 2006 and Adebola et al., 2019). However, code for beta-lactam, aminoglycoside and quinolones resistant (Adenipekun et al., 2016), knew those resistant genes detected in this study. The detection of those resistant genes in $E$. coli isolates in this study suggests that resistance to these antimicrobial agents are genetically mediated possibly because of long-term use or misuse of the antibiotics. The reports of antibiotic resistant genes found in E. coli which might indicates there is a possibility of presence of other classes of antimicrobial associated resistant genes that are not detected in this study. Therefore, there is a need for a strategies to control the rapid dissemination of these antimicrobial resistant genes through implementation of strict guidelines for counter misuse of antibiotics and also rational use of antibiotics in both human and agricultural activities and these could be the possible explanation for the emergence of multidrug resistance genes (Oloruntoba et al., 2020).

\section{CONCLUSION}

The findings of this study show augmentin, ciprofloxacin and sparfloxacin are the most effective antibiotics against $E$. 
coli isolated from patients attending the two hospitals in Damaturu; who are diagnose with UTI and diarrheic infection. The resistant genes include; blaTEM, accCl and qnrA coding for beta-lactam, aminoglycoside and quinolones were present in $E$. coli isolated from patients attending selected Hospitals in Yobe State, Nigeria that are responsible for the multidrug resistance observed. However, there is an extremely needful to strengthen a strict compliance to the use of antibiotics and enforcement of infection control practices in all our hospitals, primary health cares and pharmacies as means of controlling the increasing spread of multidrug resistance bacteria in Yobe State, Nigeria.

Acknowledgement: We acknowledge Idriss Baba Machina of Molecular Laboratory Unit, Nigerian Institute for Trypanosomiasis Research Kaduna State, Nigeria, for helping in conducting PCR analysis, Musa Ibrahim of Medical Laboratory Unit, Yobe State Specialist Hospital and Abdullahi Buba of Medical Microbiology Unit, Yobe State Teaching Hospital Damaturu- Nigeria respectively, for helping in collecting the samples and analysis.

Author's contributions: Sheriff Wakil, Mustafa Alhaji Isa and Adam Mustapha conducts the research and all authors read and approved the final manuscript.

Funding: This study was sponsor by Tertiary Education Trust Fund (TET fund) through the Institutional Based Research Grant of Yobe State University, DamaturuNigeria.

Competing interest: The authors declare that they have no competing interest.

Ethical Approval: Approved

\section{REFERENCES}

1. Aboderin OA, Abdu A, Odetoyin BW, Lamikanra A. Antimicrobial resistance in Escherichia coli strains from urinary tract infections J Natl Med Assoc. 2009; 101(12): 1268-1273.

2. Abujnah AA, Zorgani A, Sabri MAM, ElMohammady H, Khalek RA, Ghenghesh KS. Multidrug resistance and extendedspectrum beta-lactamases genes among Escherichia coli from patients with urinary tract infections in Northwestern Libya. Libyan J Medicine. 2015; 10: 26412.

3. Adam Mustapha and Turgut Imir. Detection of Multidrug - Resistance Gram-Negative Bacteria from Hospital Sewage in North East, Nigeria. Frontiers in Environmental Microbiology. Vol. 5, No. 1, 2019, pp. 1-7. doi: 10.11648/j.fem.20190501.11

4. Adebola Onanuga, Jaspreet Mahindroo2, Shreya Singh2, Neelam Taneja. Phenotypic and molecular characterization of antimicrobial resistant Escherichia coli from urinary tract infections in Port-Harcourt, Nigeria. Pan African medical journal. 2019; 34:144.

doi:10.11604/pamj.2019.34.144.18182.

5. Adenipekun EO, Jackson CR, Ramadan H, et al. Prevalence and multidrug resistance of E. coli from community-acquired infection in Lagos, Nigeria. J. infectious dev. Contries. 2016; 10(9): 920-31 doi: http://dx.org/10.3855/jidc.7997.

6. Al-mayahie, S.M., 2013. Phenotypic and genotypic comparison of ESBL production by vaginal $\mathrm{E}$. coli isolates from pregnant and non-pregnant women. Am. CLIN. Microbial. antimicrobials, vol.12.10.1186/1476-0711-12-7.

7. Anago E, Ayi-Fanou L, Akpovi CD, Hounkpe WB, Tchibozo MA, Bankole HS et al. Antibiotic resistance and genotype of betalactamase producing Escherichia coli in nosocomial infections in Cotonou, Benin. Annals of Clinical Microbiology and Antimicrobials. 2015; 14: 5.

8. Blair JMA, Mark A, Webber MA, Baylay AJ, Ogbolu DO, Piddock LJV. Molecular mechanisms of antibiotic resistance. Nature Reviews Microbiology. 2015; 13(1): 42-51.

9. Bora, A., N.K. Hazarika, S.K. Shukla, K.N. Prasad, J.B. Serma and G. Ahmed, 2014. Prevalence of blaTEM, blaCTX-M and blaSHV genes in clinical isolates of E. coli and $\mathrm{K}$. pneumoniae from northeast India. Indian journal of pathology, Microbial. 57:24-254.

10. CLSI 2016 Clinical and Laboratory Standards Institute. Performance standards 
Sheriff Wakil et.al. Phenotypic and molecular detection of resistance genes from multi-drug resistant Escherichia coli isolated from patients attending selected hospitals in Damaturu, Yobe State, Nigeria.

for antimicrobial susceptibility testing. 26th Edition, M100S. Wayne, Pennsylvania 19087 USA: Clinical and Laboratory Standards Institute. 2016.

11. D. Bansal, R. Sehgal, Y. Chawla, N. Malla, and R. C. Mahajan, "Multidrug resistance in amoebiasis patients," Indian Journal of Medical Research, vol. 124, no. 2, pp. 189194, 2006.

12. Drlica. Bansal, R. Sehgal, Y. Chawla, N. Malla, and R. C. Mahajan, "Multidrug resistance in amoebiasis patients," Indian Journal of Medical Research, vol. 124, no. 2, pp. 189-194, 2009.

13. Ensor, V.M., W. Jamal, V.O Rotimi, J.T. Evans and P.M. Hawkey, 2009. Predominance of CTX-M-15 extended spectrum beta-lactamases in diverse Escherichia coli and Klebsiella pneumoniae from hospital and community patients in Kuwait. International journal of antimicrobial agents, 33:487-489.

14. Essack, S.Y., L.M. Hall and D.M Livermore, 2004. Klebsiella pneumoniae and E. coli isolates from South Africa with multiple TEM, SHV and AMPC betalactamase. Int. J. antimicrobial agents, 23:398-400.

15. H. Nikaido, "Multidrug resistance in bacteria," Annual Review of Biochemistry, vol. 78, pp. 119-146, 2009.

16. Hujer, K.M., A.M E. A Hulten., S. Bajaksouzain and J.M Adams et al., 2006. Analysis of antibiotics resistance genes in Multidrug resistance actinobavter spp. Isolates from military and civilian patients treated at the walter reed army medical center. Antimicrobial agents' chemotherapy. 50:4114-4123.

17. Kaper, J.B.; Nataro, J.P.; Mobley, H.L. Pathogenic Escherichia coli. Nat. Rev. Microbiol. 2004, 2, 123-140.

18. Karlowsky, J.A.; Jones, M.E.; Thornsberry, C.; Friedland, I.R. Trends in antimicrobial susceptibilities among Enterobacteriaceae isolated from hospitalized patients in the United States from 1998-2001. Antimicrob. Agents Chemother. 2017, 47, 1672-1680.

19. Lee.,Noumedem, J.A., Mihasan, M., Lacmata, S.T. et al. Antibacterial activities of the methanol extracts of ten Cameroonian vegetables against Gram-negative multidrug-resistant bacteria. BMC Complement Altern Med 13, 26 (2013). https://doi.org/10.1186/1472-6882-13-26
20. M. Popęda, E. Płuciennik, and A. K. Bednarek, "Proteins in cancer resistance," Postępy Higieny i Medycyny Do'swiadczalnej, vol. 68, pp. 616-632, 2014.

21. Magiorakos AP, Srinivasan A, Carey RB, Carmeli Y, Falagas ME, Giske CG et al. Multidrug-resistant, extensively drugresistant and pandrug-resistant bacteria: an international expert proposal for interim standard definitions for acquired resistance. Clinical Microbiology and Infection. 2012; 18(3): 268-81.

22. Momtaz H, Rahimi E, Moshkelani S. Molecular detection of antimicrobial resistance genes in E. coli isolated from slaughtered commercial chicken in iran. Veterinarni medicina. 2012: 57(4): 193-97 doi: $\quad$ http://dx.doi.org/10.17221/5916VETMED.

23. Muhammad MH, Swedan S. Molecular and phenotypic characterization of carbapenem resistance and extended spectrum betalactamases among urinary Escherichia coli isolates. International Journal of Science and Technology. 2015; 5(9).

24. Ogefere HO, Aigbiremwen PA, Omoregie R. Extended Spectrum Beta-Lactamase (ESBL) producing Gram-negative isolates from urine and wound specimens in a tertiary health facility in southern Nigeria. Tropical Journal of Pharmaceutical Research. 2015; 14(6): 1089-1094.

25. Oloruntoba, F., Adabara, N., Adedeji, A., Kuta, F. and Ezeonu, C., 2020. Prevalence of multidrug resistance genes in Escherichia coli isolates from patients attending four hospitals in Minna, Nigeria. Sri Lankan Journal of Infectious Diseases, 10(1), pp.53-64.

DOI: http://doi.org/10.4038/sljid.v10i1.8269

26. Onanuga A, Selekere TL. Virulence and antimicrobial resistance of common urinary bacteria from asymptomatic students of Niger Delta University, Amassoma, Bayelsa State, Nigeria. Journal of Pharmacy and Biomedical Sciences. 2016; 8(1): 29-33.

27. Pitout JD. The lates threat in the war on antimicrobial resistance. Lancet infect Dis, 2012: $\quad 10 \quad$ (9): $578-7$ doi: http://dx.org/10.1016/S14733099(10)701687.

28. Pitout, F.; Chomton, M.; Blois, H.; Courroux, C.; Noelig, J.; Bidet, P.; Bingen, E.; Bonacorsi, S. Efficacy of bacteriophage 
Sheriff Wakil et.al. Phenotypic and molecular detection of resistance genes from multi-drug resistant Escherichia coli isolated from patients attending selected hospitals in Damaturu, Yobe State, Nigeria.

therapy in experimental sepsis and meningitis caused by a clone O25b:H4ST131 Escherichia coli strain producing CTX-M-15. Antimicrob. Agents Chemother. 2012, 56, 3568-3575. Int. J. Environ. Res. Public Health 2013, 106247.

29. Robicsek A, Strahilevitz J, Sahm DF, Jacoby GA, Hooper DC. Qnr prevalence in ceftazidime-resistant Enterobacteriaceae isolates from the United States. Antimicrob Agents Chemother. 2006 Aug; 50(8): 28724.

30. Roshan., M.A Ikram, I.A Mirtza, N. Malik, S.A Abbasi and S.A Alizai, 2011. Susceptibility pattern of extended spectrum beta-lactamse producing isolates in various clinical specimens. J.Coll.Physician. Surg. Pak.,21:342-346.

31. S. Nathisuwan, D S Burgess, J.S Lewis. Extended-spectrum beta-lactamases: epidemiology, detection, and treatment. 2001 Aug;21(8):920-8. doi: 10.1592/phco. 21.11.920.34529.

32. Salah FD, Diagbouga S, Dabire AM, Sadji AY, Nadembega C, Moumouni A et al. First detection of resistance genes encoding Extended Spectrum $\beta$-Lactamase Producing Escherichia coli at Lomé, Togo. Archives of Clinical Microbiology. 2016; 7(6): 32.

33. Stefano P, Cristain R, Maddalena G, Alberto M, Emmanuel D, Gaia $\mathrm{P}$ et al. Prevalence of multi-drug resistant E. coli in the territorial and nosocomial population. Urol Ann. 2013; 5(1): 25-29.

34. Ugbo E, Anyamene C, Orji J, Eluu S, Ukpai $\mathrm{G}$, Ogene $\mathrm{L}$ et al. Phenotypic characterization and comparative study on ESBL producing E. coli of clinical origin.
International Journal of Sciences. 2016; 5(2): 27-31.

35. V. Singh, "Antimicrobial resistance," in Microbial Pathogens and Strategies for Combating Them: Science, Technology and Education, vol. 1, pp. 291-296, Formatex Research Center, 2013.

36. World Health Organization, "Antimicrobial resistance," 2014.

37. Yoo, S.H.; Jeong, H.; Kwon, S.-K.; Kim, J.F. Genomics, Biological Features, and Biotechnological Applications of Escherichia coli B: Is B for better; Springer: Berlin, Germany, 2009.

38. Yusuf I, Haruna M, Yahaya H. Prevalence and antibiotic susceptibility of AmpC and ESBL producing clinical isolates at a tertiary health care center in Kano, NorthWest Nigeria. African Journal of Clinical and Experimental Microbiology. 2013; 14(2): 109-119.

39. Zhang, S.,Zhu, X., Wu, Q., Zhang, J., $\mathrm{Xu}, \mathrm{X}$. and Li, H. (2019). Prevalence and characterization of Escherichia coli O157 and $\mathrm{O} 157: \mathrm{H} 7$ in retail fresh raw meat in South China. Annal of Microbiology. 65 (4): 1993-1999.

How to cite this article: Wakil S, Isa MA, Mustapa A. Phenotypic and molecular detection of resistance genes from multi-drug resistant Escherichia coli isolated from patients attending selected hospitals in Damaturu, Yobe State, Nigeria. International Journal of Research and Review. 2021; 8(9): 396-407. DOI: https:// doi.org/10.52403/ijrr.20210951 